\title{
Los judeoconversos en la Corte y en la época de los Reyes Católicos: una interpretación de conjunto
}

\author{
María del Pilar Rábade Obradó *
}

Finalizando ya el reinado de los Reyes Católicos, durante los primeros años del siglo XVI, la población conversa hispana estaba compuesta por unas 300.000 personas, aproximadamente un 5 o un 6 por 100 del total de la población española ${ }^{1}$. Aunque no se trata de un porcentaje especialmente elevado, lo cierto es que los cristianos nuevos se habían configurado como un colectivo esencial en el seno de la sociedad hispana, a la par que como un grupo caracterizado por toda una serie de singularidades y peculiaridades, que, en gran medida, se habían ido forjando a lo largo del reinado de Isabel y Fernando.

Protagonista de una fuerte implantación urbana ${ }^{2}$, el colectivo converso estaba comandado por una élite, siempre pronta a mezclarse con la población cristiana vieja ${ }^{3}$, élite que había logrado acceder a una evidente

* Universidad Complutense.

Domínguez Ortiz, A., La clase social de los conversos en Castilla en la Edad Media. Madrid 1955, pág. 141. Evidentemente, se trata de una minoría, aunque bastante más numerosa que la minoría judía, que debía estar compuesta por unas 100.000 almas, tal como señala LADERO QuesadA, M. A., "Le nombre des juifs dans le Castille du xvème siècle", Proceedings of the Sixth Congress of Jewish Studies, II. Jerusalén 1975, págs. 45-52.

2 La cuestión ha suscitado el interés de numerosos investigadores. Uno de los primeros en señalarlo fue Domínguez OrTiz , A., op. cit., pág. 141. Sin embargo, tampoco puede desdeñarse la presencia de cristianos nuevos en el ámbito rural, y especialmente en las tierras de señorio de los grandes nobles, debido, entre otras cosas, a la protección que aquéllos les dispensaban; sobre esta cuestión, ver LADERo QueSADA, M. A., "Judeoconversos andaluces en el siglo XV", Actas del III Coloquio de Historia Medieval Andaluza. La sociedad medieval andaluza: grupos no privilegiados. Jaén 1984, págs. $27-55$ (pág. 47).

3 Hecho destacado por Ladero Quesada, M. A., España en 1492. Madrid 1978, pág. 58, y en el que igualmente insiste GutiÉrRez NIETO, J. I., "La estructura castizo-estamental de la sociedad castellana del siglo XV|», Hispania, 125, 1973, págs. 519-563 (págs. 538-539). Ver, asimismo, Márquez Villanueva, F., "The Converso Problem: an Assesment", en Hornik, M.P. (ed.), Collected Studies in Honor of Americo Castro's Eightieth Year, 2. ${ }^{a}$ ed. Oxford 1975, pág. $317-33$. 
promoción económica y social, introduciéndose en los sectores dirigentes del reino, tanto a nivel local - recuérdese su penetración en la administración concejil ${ }^{4}$ - como a otros niveles superiores, hecho ejemplificado en los numerosos oficiales regios que acogía la Corte ${ }^{5}$.

Pero esta élite es sólo una pequeña parte del colectivo cristiano nuevo, conformado fundamentalmente por una masa que ha de ser asimilada, por su situación socio-económica, a los sectores intermedios de la sociedad, e incluso a las capas más desfavorecidas de la misma: la documentación indica, por tanto, la necesidad de desmitificar la imagen del converso dotado de grandes recursos económicos, dedicado a actividades financieras, ejerciendo un poder poco menos que omnímodo sobre los cristianos viejos, a los que podía señorear a su antojo ${ }^{6}$. Esta tópica imagen se hace realidad en ocasiones, pero se desvanece ante el cristiano nuevo medio: artesano o tendero, con escasos o regulares medios económicos, que no participa ni en la toma de decisiones políticas ni en su

Se trata, además, de una realidad perfectamente constatada por sus propios contemporáneos: Díaz de TOledo, Fernando, en su Instrucción del Relator (editada por Alenso, M. Defensorium Unitatis Christianae de Alonso de Cartagena. Madrid 1943, págs. 343-356), no dudaba en afirmar que «si bien se escudriñara, se fallarse ha que todos los estados, quien de más lueñe, quien otros de más cerca, todos están bueltos unos con otros en este linaje (el de los cristianos nuevos)... e ansí se continuará hasta la fin del mundo" (pág. 355). A pesar de la posible exa. geración, achacable al hecho de ser el propio autor de estas líneas descendiente de neófitos, lo cierto es que tampoco le debia faltar mucha razón cuando resaltaba la mezcla de sangre que se había efectuado.

4 Esta cuestión ha sido magistralmente estudiada por MÁrouez VILLANUEVA, F., “Conversos y cargos concejiles en el siglo XV", Revista de Archivos, Bibliotecas y Museos, 63, 1957, págs. 503-540. Ver, también, Haliczer, S., "The Castilian Urban Patriciate and the Jewish Expulsión of 1492", American Historial Review, 78, 1973, págs. 35-58.

5 En este aspecto insiste MÁrquez VILLANUEVA, F., Investigaciones sobre Juan Álvarez Gato. Contribución al estudio de la literatura castellana del siglo XV, 2. ${ }^{a}$ ed. Madrid 1974, así como Chaunu, P., La España de Carlos V, 2 vols. Barcelona 1976 (I, pág. 127). BAeA, Y., Historia de los judíos en la España cristiana, 2 vols. Madrid 1981, ilustra esta cuestión con las siguientes palabras: «había buenas razones para el mutuo entendimiento entre los jóvenes príncipes y sus auxiliares de estirpe judía. Los judíos y los conversos... estaban dispuestos a apoyar a una monarquia fuerte que impusiera el orden y la confianza en el pais, sin importarles a priori las consecuencias religiosas que pudieran derivarse de ello en el futuro" (pág. 551). Los propios contemporáneos de Isabel y Fernando observaron, a veces con asombro, la masiva presencia de oficiales judios o de origen hebreo en su Corte; este es el caso de Nicolás de Popielovo, noble polaco, viajero por tierras peninsulares en los últimos años del siglo xv, que no dudaba en afirmar en sus memorias que Isabel protegía a los judíos, al tiempo que tanto ella como su regio esposo mostraban hacia los cristianos nuevos una confianza mayor que hacia los cristianos viejos, escogiendo de entre aquéllos a sus secretarios y consejeros. Recoge estas aseveraciones Garcia Mercadal, J., España vista por los extranjeros, varios vols. Madrid, s. a., vol. I, pág. 203.

8 Se trata, efectivamente, de afirmaciones que han adquirido ya carácter de tópico, por lo que se pueden localizar prácticamente en todo trabajo consagrado a la problemática de los cristianos nuevos. 
control, cifrando todos sus esfuerzos en la lucha por mantenerse a flote en un mundo que no acostumbraba a respetar a los humildes ${ }^{7}$.

El reinado de los Reyes Católicos supone para los cristianos nuevos, independientemente de su pertenencia a la élite o al común de ese colectivo, toda una serie de novedades; entre ellas, se ha de destacar, por su incidencia y consecuencias de cara al futuro, el acoso social e institucional de que fue objeto el grupo, un acoso social e institucional que se ha de poner en relación con el supuesto peligro que implicaba para la sociedad cristiana la presencia de conversos en su seno.

¿Existía en realidad ese peligro converso?, ¿podían los cristianos nuevos ejercer una acción corrosiva y disolvente sobre los principios que mantenian a la sociedad cristiana, sobre los fundamentos del cristianismo? Para los contemporáneos de Isabel y Fernando, la respuesta a estos dos interrogantes es afirmativa ${ }^{8}$. Existe un peligro converso materializado no

7 Ya en un trabajo anterior expusimos un somero estudio relativo a las coordenadas socioeconómicas que mediatizaban al colectivo converso durante el reinado de los Reyes Católicos, estudio que arrojaba, en lo que se refiere a las actividades profesionales, los siguientes porcentajes: actividades agropecuarias, 1,92 por 100; artesanía textil, del vestido y del calzado, 37,4 por 100; otras actividades artesanales, 9,88 por 100 ; actividades comerciales, 18,23 por 100; actividades financieras, 2,91 por 100; profesionales de la sanidad, 4,7 por 100; eclesiásticos, 3,77 por 100; servicio doméstico, 3,71 por 100; oficios públicos, 16,5 por 100; varios, 0,92 por 100 . En cuanto a los niveles de renta, arrojaba los siguientes porcentajes: fortunas inferiores a 30.000 maravedís, 40,9 por 100 ; fortunas entre 30.000 y 100.000 maravedis, 17 por 100 ; fortunas superiores a 100.000 maravedís, 5,57 por 100 , a lo que hay que unir el porcentaje representado por aquéllos que se declaran indigentes. Se hace, por tanto, patente que la gran mayoría de los conversos se hallaban incluidos en las capas medias y bajas de la sociedad, detentando, lógicamente, oficios en consonancia, asi como niveles de renta medios o bajos. De todas formas, no se puede olvidar que junto a ellos también habia neófitos que gozaban de una más elevada posición económica, y entre ellos, lógicamente, los oficiales de Corte. Sobre estas cuestiones, consultar RÁbAde Obrado, M. P., Los judeoconversos en la Corte y en la época de los reyes católicos. Madrid 1990, págs. 453 y ss.

8 Y no sólo para ellos: autores contemporáneos han glosado retóricamente este "peligro", magnificando la situación hasta hacerla pasar por insostenible, con el único propósito de proceder a una justificación tanto del establecimiento de la Inquisición como de la expulsión de los judíos. Así, por ejemplo, Giménez Soler, A., Fernando el Católico. Barcelona 1941, pág. 105, asegura que existia el peligro de que judios y conversos unidos "se apoderasen de los cargos de la gobernación y dirigiesen el estado hacia sus fines, como de hecho estaba sucediendo ya, sobre todo en Aragón y en la misma Corte de Don Fernando". López MARTínez, N., Los judaizantes castellanos en tiempos de Isabel la Católica. Burgos 1959, págs. 203 y ss., va más allá, afirmando que hebreos y neófitos ceran, pues, una raza fuerte, unida, siempre en tensión vital. Diriamos que capaz de todo. Puesta frente al cristianismo -en cuya enemiga volcaban su peso-constituyó un adversario formidable. Añádase que conviven con cristianos y en proporción elevadísima, que en su mayoría se decian cristianos, que manejaban todos los resortes de poder e influencia, que eran tiempos en que lo religioso interesaba vitalmente: nadie podrá ya negar, ni dudar siquiera, que suponian un gravísimo peligro para el catolicismo castellano", añadiendo poco más adelante que ellos habían provocado la aparición de "una atmósfera de confusionismo e indiferencia» con su «influencia avasalladora", por lo que se ca- 
sólo en aquellos que, aunque cristianos de nombre, siguen aferrados a la ley de Moisés, o en aquellos otros que se hallaban inmersos en el escepticismo religioso; se materializaba, igualmente, en aquellos que practicaban un cristianismo sincrético, mezcla de prácticas y ceremonias efectivamente cristianas con otras propiamente judías, y se plasmaba, finalmente, en aquellos que luchaban patéticamente por hallar su identidad religiosa, sin ser capaces de encontrarse a gusto ni como judios ni como cristianos ${ }^{9}$.

Esta evidente pluralidad religiosa del grupo cristiano nuevo no va a acarrear más que probiemas para la generalidad del colectivo, obligado a luchar contra la muy extendida idea de que los miembros del grupo que además eran buenos cristianos eran tan sólo una minoría, si bien lo cierto es que tampoco hay razones fidedignas para dudar de la sinceridad de la conversión de muchos, ni del fervor cristiano de bastantes de los descendientes de judíos que nacieron ya en el seno de familias cristianas ${ }^{10}$.

minaba hacia "un renacer paganizante, descristianizador». El mismo autor vierte parecidas opiniones en un articulo dedicado específicamente a esta cuestión, "El peligro de los conversos", Hispania Sacra, II, 1950, págs. 3-63. Finalmente, traemos a colación la opinión de SANCHO DE Sopranis, H., "Los conversos y la Inquisición primitiva en Jerez de la Frontera, 1486-1496", Archivo Iberoamericano, octubre-diciembre, 1944, págs. 595-610, que, tras confirmar la existencia del peligro judio y converso, termina por reconocer que se produce una "agravación del mismo por el exagerado celo de frailes y cristianos viejos, quienes por todas partes veian peligros, más imaginarios que reales..." (pág. 598).

9 Esta clasificación de las actitudes religiosas de los conversos - a la cual hay que unir, lógicamente, la representada por los cristianos sinceros- ha sido ofrecida por Dominguez ORTIZ, A., "Historical Research of Spanish Conversos in the Last Fifteen Years", en HORNIK, M. P. (ed.), op. cit., págs. 63-82 (pág. 82). Los procesos inquisitoriales ilustran suficientemente estos cinco grandes modelos de comportamiento religioso converso, aunque casi se podría afirmar que existen tantas actitudes religiosas como conversos; algunos ejemplos, en RÁBADE OBRADó, M. P., op. cit., págs. 342 y ss., así como en RÁbade Obradó, M. P., “Expresiones de la religiosidad cristiana en los procesos contra los judaizantes del Tribunal de Ciudad Real/Toledo, 14831507", En la España Medieval, 13, 1990, págs. 303-330.

10 En este aspecto inciden algunos ilustres conversos del momento, al tratar de defender a su colectivo de la acusación de generalizada deslealtad hacia el cristianismo: CARTAGENA, Alonso de, en su Defensorium Unitatis Christianae (ed. por Alenso, M., en Madrid 1943); DíAZ DE TOLEDO, Fernando, en su Instrucción del Relator (ed. como apéndice de la anteriormente citada obra de Alonso de Cartagena); Talavera, Fray H. de, en su Católica impugnación (ed. por Martín Hernández, F. y Márquez Villanueva, F., en Barcelona 1961), Fray Lope de Barrientos, en su opúsculo Contra algunos cizañadores de la nación de los convertidos del pueblo de Israel (ed. por Getino, L. A. G., Vida y obras de Fray Lope de Barrientos. Salamanca 1927)... De la opinión contraria son otros, entre los que se puede destacar, por ejemplo, al anónimo autor del textito satírico editado por PFLAUM, $\mathrm{H}$., "Une ancienne satire espagnole contre les marranos", Revue des Etudes Juives, LXXXVI, 1928, págs. 131-150, asi como el igualmente anónimo autor del Libro del alborayque, editado por LóPEz MARTínez, N. op. cit. Se trata, además, de una opinión muy generalizada entre los autores contemporáneos, tal vez influidos por MENÉNDEZ Pelayo, M., Historia de los heterodoxos españoles, 2 vols. Madrid 1956 (reed.), que no vacilaban en mostrar sus dudas acerca de la conversión de los más de los cristianos nuevos (vol. I, pág. 725). 
Es la necesidad de discernir entre conversos sinceros e insinceros, es la necesidad de separar a estos últimos del resto de la sociedad, es la necesidad de castigar a estos falsos conversos, la que provoca el nacimiento, primero de la Inquisición y luego de los Estatutos de limpieza de sangre, los dos procedimientos más restrictivos a los que acuden los cristianos viejos para frenar el peligro converso.

El Santo Oficio se limita -o pretende limitarse- a separar a los falsos conversos del resto de la sociedad, mediante, incluso, su eliminación física. Su utilización nos indica cómo el problema converso es, fundamentalmente, un problema religioso, que se pretende solucionar, subsiguientemente, por la vía religiosa ": son las peculiaridades religiosas de los cristianos nuevos, su supuesta apostasía, las que provocan la aparición de la Inquisición. Se teme que la presencia de falsos conversos en el seno de la sociedad cristiana pueda provocar un envilecimiento del cristianismo, al tiempo que también se temen los efectos de un posible proselitismo de esos falsos conversos. El Santo Oficio surge para potenciar una auténtica unificación espiritual y religiosa en el seno de los reinos de Isabel y Fernando, en consecuencia con los ideales políticos que empiezan a expandirse en ese momento, ideales que relacionan estrechamente comunidad política e identidad religiosa ${ }^{12}$.

11 Este carácter esencialmente religioso del Santo Oficio es algo ya plenamente reconocido por BAER, Y., op. cit., pág. 573, cuando afirma que "la Inquisición española se fundó como una institución eclesiástica, y, por tanto, dependiente, como la anterior Inquisición general, de la aprobación del Papa. Estaba destinada a solucionar un problema socio-religioso especial dentro de la política religiosa de un país particular y por ello se convirtió en una institución estatal, si bien su carácter religioso puro nunca llegó a borrarsem. Sin embargo, se trata de una opinión no compartida por todos los estudiosos de la materia, tal como se pone de relieve en RÁBADE Obadó, M.P., Los judeoconversos..., págs. 68 y ss. Finalmente, conviene no olvidar que el Santo Oficio, junto a esa orientación esencialmente religiosa, también presenta una orientación social, que empieza a hacerse más evidente durante ia evolución histórica de la institución a lo largo de los reinados de los sucesores de los Reyes Católicos.

${ }_{12}$ Recuérdese la teoría del máximo religioso, expuesta magistralmente tantas y tantas veces por SuÁrez FERNÁNDEZ, L., que vuelve a insistir en esta cuestión en su última monografía, La expulsión de los judios de España. Madrid 1991, págs. 299-300. Desde este punto de vista, el Santo Oficio, tal como indica Huerga Criado, P., aEl Inquisidor General Fray Tomás de Torquemada. Una Inquisición nuevam, en Inquisición española. Nuevas aproximaciones. Madrid 1987, págs. 7-51, nacería "como institución del Estado Moderno, bajo la autoridad suprema de la Corona, e integrada en la administración central a través del Consejo Real y Supremo de la Inquisición, para contribuir a la formación del nuevo Estado y asegurar su estabilidad". Tal como recuerda Pérez, J., Isabel y Fernando, Reyes Católicos de España. Madrid 1989, págs. 344, «se trata, en el caso de España, de construir una nación ideológicamente homogénea. Para ser un buen ciudadano, no basta con respetar las leyes del reino, pagar los impuestos, servir lealmente a la patria; además, hay que practicar la religión católica". O sea, que se confunden política y religión. 
Por su parte, los Estatutos de Limpieza de Sangre suponen un segundo paso, pues abren las puerta a la eliminación social de la totalidad de los cristianos nuevos, sin entrar en distinciones religiosas ${ }^{13}$; amenazan con condenar al ostracismo social a los conversos, justificándolo sobre la base de las crecientes suspicacias de la población cristiana vieja hacia el conjunto del colectivo cristiano nuevo. Evidentemente, el problema converso empieza a teñirse de connotaciones racistas.

Sin embargo, no se debe exagerar la incidencia de los Estatutos de Limpieza de Sangre a lo largo del reinado de los Reyes Católicos, pues su extensión fue bastante limitada hasta los tiempos de su sucesor ${ }^{14}$, cuando empezaron a proliferar con gran rapidez ${ }^{15}$. Conviene no olvidar que dichos Estatutos no afectaban a la totalidad de la población conversa, pues, exceptuando los relativos a las Ordenes Religiosas ${ }^{16}$, los otros se referían a cargos y honores que sólo podian disfrutar aquellos cristianos nuevos que ostentaban una elevada posición económico-social, y para

13 Tal como indica Rivkin, E., "How Jewish Were the New Christians?", en Sola Sole, J. M., et alii, Hispania judaica. Barcelona 1980, págs. 103-115, las consecuencias de la aplicación de los Estatutos de Limpieza de Sangre suponian que se privaba a los conversos de los derechos que habían adquirido como cristianos tras su conversión, sin hacer distinción entre los que judaizaban y los que se mantenian leales a la fe de Cristo. Los neófitos, si su comportamiento cristiano era irreprochable, podían escapar a la acción inquisitorial, pero podian verse irremisiblemente afectados por los Estatutos, que les discriminaban por el mero hecho de llevar sangre judia en sus venas, independientemente de cualquier otro tipo de condicionamientos (pág. 109).

14 Su precedente más directo y más obvio es la Sentencia-Estatuto de Pero Sarmiento, promulgada en Toledo en 1449 y estudiada esencialmente por BENITO RuANO, E., Toledo en el siglo XV. Madrid 1961, y Los orígenes del problema converso. Barcelona 1976. Durante el reinado de Isabel y Fernando, rompió el fuego el Estatuto impuesto por la Orden Jerónima, de corta existencia, pues no tardó mucho en ser suprimido, tras ser objeto de fuertes controversias en el seno de la misma Orden. Sigüenza, J. de, Historia de la Orden de San Jerónimo, 2 vols. Madrid 1966, vol. II, págs. 33 y ss., relata con gran lujo de detalles los avatares que hubo de padecer el Estatuto, a cuyo estudio se han consagrado dos monografias: CARRETE PARRONDO, C., "Los conversos jerónimos ante el Estatuto de Limpieza de Sangre", Helmantica, XXVI, 1975, págs. 97-116; OrfALI, M., "Establecimiento de Estatuto de Limpieza de Sangre en el Monasterio de los Jerónimos de Guadalupe», Jornadas de Estudios Sefardíes, págs. 245-250. La bibliografía sobre esta cuestión es abundantísima. Para una primera aproximación al tema, ver CARO BARojA, J., Los judios en la España Moderna y Contemporánea, 3 vols. Madrid 1978; Chaunu, P., La España de Carlos V, 2 vols. Barcelona 1976; Dominguez OrTIZ, A., op. cit., así como Los judeoconversos en España y América. Madrid 1971 y SıCRof, A. A., Les controverses des Status de "Pureté de Sang" en Espagne du XVe au XVIle siècle. París 1960.

15 Tal como señala GutiÉrRez Nieto, J. 1., op. cit., pág. 553 , que señala cómo dicha proliferación se ha de poner en directa relación con el fracaso de las Comunidades, haciéndose especialmente virulenta a lo largo de la década de los cuarenta del siglo xvi, coincidiendo con lo que este autor denomina "neohidalguismo».

16 Unas Ordenes Religiosas que, tal como señala Dominguez ORTız, A., Los judeoconversos..., págs. 99 y ss., no se mostraban especialmente propicias a su instauración. 
éstos siempre era posible recurrir a la compra de testigos, con objeto de buscar así la confirmación de sus supuestos orígenes cristianos viejos, amparándose en igualmente supuestos y acomodaticios antepasados norteños; en otros casos, bastaba con el recurso a procedimientos menos sutiles, aunque igualmente eficaces: un oportuno cambio de apellidos, o un traslado de domicilio, que, si se llevaban a cabo con la suficiente habilidad, podía reportar grandes ventajas a los que se valian de ellos, podían llegar a borrar la huella del propio origen, facilitando el camino del ingreso en el colectivo cristiano viejo de los que así obraban ${ }^{17}$.

En cuanto al Santo Oficio, éste actuó tan sólo sobre una minoría ${ }^{18}$, y además dicha actuación quedó claramente delimitada por las coordenadas espaciales y temporales: así, mientras que prácticamente no dejó huella en la mitad septentrional de la Península, sí dejó una profunda impronta en su parte más meridional ${ }^{19}$; mientras que la Inquisición inició su andadura con una actividad febril, durante los últimos años del reinado de Isabel y Fernando entró en una evidente fase de apatía ${ }^{20}$.

Además, incluso aquellos que habían sufrido en sus propias carnes el embate inquisitorial podían encontrar una salida a la infamia que esto suponía, podían solicitar su pleno reingreso en la sociedad cristiana mediante su acogida a la política de habilitaciones y composiciones, que evitaban que las propiedades de los condenados pasaran a integrar los fondos del fisco regio, al tiempo que volvían a otorgar sus derechos como miembros de la comunidad cristiana a los que previamente habian sido apartados de ella ${ }^{21}$.

17 Sobre estas cuestiones, consultar GiLMAN, S., La España de Fernando de Rojas. Panorama intelectual y social de "La Celestina". Madrid 1988, págs. 51 y ss. MÁRQUEz ViLLANUEVA, F., “The Convers Problem...", pág. 59, insiste en la escasa seriedad con la que se realizaban los expedientes de las pruebas de Limpieza de Sangre, lo que facilitaba la ocultación de la ascendencia hebrea.

${ }_{18}$ Tal como indica Ladero Quesada, M. A., "Judeoconversos andaluces...", pág. 41. De todas formas, tampoco se puede olvidar que la Inquisición, aunque sólo afectara a una minoría, pudo influir negativamente en la vida de una gran parte de los cristianos nuevos, pues «su gestión... al prodigarse sobre la generalidad masiva de la población conversa, somete indiscriminadamente a la inquietud y a la inseguridad, anímicas y civiles, tanto a falsos como a verdaderos convertidos", tal como asevera BENITO RuANO, E., De la alteridad en la Historia. Madrid 1988, pág. 88 .

${ }_{19}$ Ver Contreras, J. y Dedieu , J.P., “Geografía de la Inquisición española. La formación de los distritos, 1480-1820", Hispania, XL, 1980, págs. 37-93.

20 Consultar Rábade Obaadó, M. P., Los judeoconversos..., págs. 984 y ss.

21 Esta política se generaliza a partir del año 1495 , si bien con anterioridad ya había dado algunos frutos. La frecuencia con que se recurre a la misma a partir de esta etapa parece deberse al «deseo de completar la ruda acción inquisitorial con un proceso rápido de mezcla y dispersión de los judeoconversos entre los cristianos viejos, para impedir que su misma continuidad como grupo prolongase la existencia de brotes de apostasía», SUÁREZ FERNÁNDEZ, L. 
Se hace evidente que durante el reinado de los Reyes Católicos no se produjo un intento consciente y premeditado destinado a convertir a los conversos en súbditos de segunda categoría: lo que se intentó fue evitar las consecuencias negativas que podía acarrear a la sociedad cristiana la presencia en su seno de falsos conversos, de cristianos nuevos que no se acogían a la más estricta ortodoxia. En este orden de cosas, los monarcas, igual que estaban dispuestos a castigar, también lo estaban a perdonar; igual que ponían los medios para llevar a cabo el acoso social e institucional contra los cristianos nuevos, también ponían los medios e instrumentos necesarios para que pudieran sustraerse a ese acoso ${ }^{22}$.

En estas circunstancias, la España de los Reyes Católicos, aunque es la España de los primeros tribunales inquisitoriales, aunque es la España de los primeros Estatutos de Limpieza de Sangre, es también una España en la que todavía ser converso no implicaba renunciar al medro personal y familiar: se trata de una España en la que aún es posible el triunfo converso; si bien ya prenuncia y predetermina la España intolerante, todavía no lo es ${ }^{23}$.

Un claro exponente de las posibilidades de medro que el reinado de Isabel y Fernando ofrece todavía a los cristianos nuevos es el relativo a los numerosos oficiales regios de ascendencia hebrea que lograron triunfar en la misma Corte de los soberanos ${ }^{24}$. Hombres como Fernando Ál-

(dir.), Los Trastámara y la unidad española (1369-1517), vol. V de la Historia General de España y América. Madrid 1981, pág. 90 . Se trata de una política destinada, evidentemente, a paliar los efectos más nocivos de más de diez años de acción inquisitorial, durante los cuales una porción del colectivo converso se había visto afectada, en mayor o menor medida, por la misma, hecho que propiciaba una tendencia a la marginación de los miembros de ese grupo, proceso que se pretende corregir, tras observar su negativa incidencia. Un estado de la cuestión, en RÁBADE Obradó, M. P., Los judeoconversos..., págs. 224 y ss.

${ }^{22}$ Márquez Villanueva, F., "Conversos y cargos concejiles...", pág. 540, asevera que "en realidad, los conversos pudieron llevar casi siempre... una vida bastante tranquila y decididamente próspera, a condición de que tuviesen la prudencia y la buena fortuna de no crearse demasiados enemigos que algún día les pudieran empatar las probanzas de algún hábito o testimoniar contra ellos la práctica de algún vago y casi folklórico signo de judaísmo...”.

${ }^{23}$ Bien es verdad que los soberanos dejaron a su sucesor una herencia intolerable, por lo que "contribuyeron a establecer un sistema insidioso que acabará por emponzoñar el espíritu público de España: será la intolerancia organizada, el recurso a la delación, la presión demagógica de los cristianos nuevos contra las élites, la instalación del conformismo ideológicom, tal como afirma Pérez, J., op. cit., pág. 413. No era lo que los propios Reyes Católicos deseaban, pero sí era lo que estaban sembrando con su proceder, siembra, que germinaría más adelante, ya en el reinado de Carlos.

${ }_{24}$ Tal como señala Márquez Villanueva, F., "Conversos y cargos concejiles...", pág. 522 , el Santo Oficio y los Estatutos de Limpieza de Sangre no fueron óbice para que el palacio de los Reyes Católicos, "su cancillería y su diplomacia siguieran, a pesar de ello, servidos por un gran número de cristianos nuevos". 
varez de Toledo, Juan Arias de Ávila, Andrés de Cabrera, Hernando del Pulgar, Fray Hernando de Talavera, Diego de Valera... ejemplifican en sus carreras como servidores de la monarquía las posibilidades que aún en esa etapa se ofrecían a los conversos.

Todos ellos pudieron ejercer sus tareas como oficiales regios sin padecer contradicciones a causa de sus orígenes judíos, orígenes que en ningún momento pretendieron ocultar ${ }^{25}$, públicamente conocidos en el ámbito cortesano, aunque, años más tarde, sus vástagos, habitantes de una España intolerante, que oponía numerosas trabas a los descendientes de hebreos, se verán impulsados a ocultar dicha ascendencia, procediendo a la invención de genealogías más o menos fantásticas, que frecuentemente buscan consolidar un teórico entronque familiar con linajes cristianos viejos ${ }^{26}$.

Vástagos de familias profundamente enraizadas en las oligarquías de sus ciudades natales, con fuertes intereses de carácter urbano, ejemplificados en su intervención en la vida ciudadana a través de su penetración en la administración concejil ${ }^{27}$, son, al mismo tiempo, miembros de fa-

25 Este es el caso, entre otros, de Juan Arias de Ávila, cuyos padres se habían convertido al cristianismo en su infancia, que, siendo ya Obispo de Segovia, seguía teniendo numerosos parientes judios, con los que se relacionaba en algunas ocasiones, tal como se hace patente en las testificaciones que contra su familia recogió la Inquisición, publicadas por CARRETE PA. RRONDO, C., Proceso inquisitorial contra los Arias Dávila segovianos: un enfrentamiento social entre judios y conversos. Salamanca 1986. Este es, igualmente, el caso de Hernando del Pulgar, o de los secretarios regios Fernando Álvarez de Toledo o Alfonso de Ávila, cuya ascendencia hebrea, tal como indica el propio cronista - Letra XXXI, dirigida al Cardenal de España, editada por Domínguez Bordona A. J., en Madrid 1958, págs. 137-138-, era sobradamente conocida en la Corte de Isabel y Fernando.

${ }_{26}$ Caso paradigmático es el de la familia Coronel, cuyas dos ramas -Núñez Coronel y Pérez Coronel-surgen a raiz de la conversión al cristianismo, en 1492, de Rabí Meyr Melamed y de Abrahem Seneor, respectivamente; a pesar de esta tan próxima ascendencia hebrea, la familia procedió a la fabricación de una honrada genealogía cristiana vieja, en un inútil intento por hacer olvidar sus orígenes hebreos, demasiado diáfanos y evidentes para poder ser ocultados. Dicha genealogía consta en el traslado que, andando, 1781, se realizó de su Ejecutoria de Hidalguía, concedida por los Reyes Católicos a Fernán Pérez Coronel, otrora Abrahem Seneor, y ha sido publicada por HERnANDo, T., "Luis y Antonio Núñez Coronel», Estudios Segovianos, XXI, 1969, págs. 385-422.

${ }_{27}$ Especialmente relevante es, en este sentido, el linaje del secretario regio Fernando Álvarez de Toledo; su grado de penetración en la administración concejil está perfectamente representado por la cantidad ciertamente notable de oficios de regimiento que fueron acumulados por los miembros varones de la familia, pues todos ellos -excepción hecha de los eclesiásticos- parecen haber gozado de dichos oficios en la ciudad de Toledo (Rábade OBRADó, M. P., Los judeoconversos..., pág. 543). También los Álvarez de Toledo se valieron de un segundo -y secundario- medio de intervención en el ámbito urbano, como es el relativo a la obtención de cargos eclesiásticos de significación local, tal como evidencia de manera muy patente la carrera de Francisco Álvarez de Toledo (hermano del secretario regio), Canónigo y Maestresala de la Catedral de Toledo, cuyos sobrinos - entre ellos, un hijo del Secretario, 
milias también marcadas por su especial relación con la corona, relación mediatizada por el servicio a aquélla ${ }^{28}$, hecho que es frecuentemente aprovechado para introducirse en los ambientes cortesanos. De hecho, se produce una fuerte tendencia a la creación de auténticas dinastías familiares al servicio de la Corona, fomentadas en parte por la hereditariedad de determinados cargos y oficios, que pasaban de padres a hijos sin solución de continuidad, en parte porque se observa el interés por colocar en la Corte a parientes y allegados ${ }^{29}$.

Una vez en la Corte, sus posibilidades de promoción caminan estrechamente unidas a sus propias capacidades, así como a su constante permanencia al servicio de la Corona, con una extrema dedicación, ejercida desde la juventud hasta la senectud, y a través de los más diversos cargos y oficios, de distinto calibre e importancia, siendo frecuente la tenencia acumulativa y sincrónica de los mismos ${ }^{30}$. Efectivamente, lo nor-

Bernardino de Alcaraz - tras su fallecimiento, mantuvieron viva la llama encendida por su tío, consolidando la posición preeminente de la familia en el seno del Cabildo toledano (RÁBADE Obradó, M. P., Los judeoconversos..., págs. 765 y ss.), siendo su influencia de tal calibre que incluso se ha llegado a afirmar que el Estatuto de limpieza de sangre que acabó afectando a dicho Cabildo fue promovido e instaurado justamente para cercenar la influencia de este grupo familiar en el seno de la Iglesia toledana (Gómez MENOR, J., Cristianos nuevos y mercaderes de Toledo. Toledo 1971, pág. LVII).

${ }_{28}$ El ejemplo más notable es el aportado por los Arias de Ávila. El iniciador del linaje, Diego, fue uno de los más notables oficiales de Enrique IV, reuniendo en su persona una ingente cantidad de oficios (RÁbade Obradó, M. P., Los judeoconversos..., págs. 774 y ss., ofrece un listado de los mismos), muchos de los cuales, indudablemente, hubieron de ser servidos a través de lugartenientes; tanto sus tres hijos varones, Pedro, Juan y Francisco como su yerno, Gómez González de la Hoz, fueron también oficiales de la Corona (sobre esta cuestión, ver Rábade Obradó, M. P., Los judeoconversos..., págs. 552-565, así como págs. 774-803), dando, de esta forma, la medida de una familia dedicada al servicio de la monarquia.

29 Tal como ya puso de relieve MACKay, A., "Popular Movements and progroms in 15th Century Castile», Past and Present, 55, 1972, págs. 33-67 (pág. 48). Los ejemplos son muy abundantes. Se puede destacar, entre ellos, al portado por la familia Alcocer, La "dinastía" es iniciada por Fernando Díaz de Alcocer, escribano de cámara de Juan II, viéndose continuada por la totalidad de sus hijos varones, dedicados, en diversos cometidos, al servicio de la Corona, destacando especialmente dos de ellos, el Doctor Juan Díaz de Alcocer y García de Alcocer, algunos de cuyos vástagos también se consagrarán al servicio de la monarquía (RÁBADE Obradó, M. P., Los judeoconversos..., págs. 579-587, así como págs. 821-829).

30 Es algo que se observa en la totalidad de los oficiales regios conversos al servicio de los Reyes Católicos. Uno de los casos más paradigmáticos es el ejemplificado por Fernando Álvarez de Toledo, que, a lo largo de su carrera, llegó a ostentar los siguientes oficios: secretario regio; miembro del Consejo; lugarteniente del escribano mayor de privilegios y confirmaciones; lugarteniente del concertador y confirmador de privilegios; notario mayor de privilegios y confirmaciones; notario mayor de Granada; escribano mayor del marquesado Villena; escribano mayor de la merindad de Asturias y las Cuatro Villas; escribano mayor de la merindad de Castilla la Vieja, Bureba, Rioja...; tesorero; contador mayor de cuentas; contador mayor de cuentas de la Orden de Santiago; alcaide de Andarax. Bien es verdad que no todos estos oficios fueron servidos sincrónicamente, pues varios fueron renunciados al poco de ser obtenidos; pero, sea como sea, lo cierto es que nuestro hombre estaba acostumbrado a servir al mismo tiempo varios 
mal era que se sirvieran varios oficios al mismo tiempo, lo que a veces implicaba el necesario recurso a lugartenientes. Además, en ocasiones, los oficios ostentados eran de muy diferentes características e indoles ${ }^{31}$, lo que obligaba a estos oficiales a desplegar una intensa y variada actividad, que ponía a prueba su talento y aptitudes. La brillantez con la que los servidores de la Corona eran capaces de llevar a cabo tareas tan diferentes y dispares da idea de la eficacia de los procedimientos de selección de oficiales mantenidos por los Reyes Católicos, siempre preocupados por esta cuestión ${ }^{32}$. En este sentido, cabe destacar que, frente al tópico relativo a la abundancia de oficiales letrados en la Corte de Isabel y Fernando, no parece existir una especial preferencia hacia aquéllos: los soberanos no paran mientes en títulos académicos, sino en los merecimientos personales de cada uno ${ }^{33}$.

También es habitual que estos oficiales de Corte ejerzan su labor como tales a lo largo de varios reinados sucesivos, sin que esto sea óbice para el avance de su carrera, haciéndose evidente la importancia que se concedía a su talento y aptitudes personales, así como a la disciplina adquirida a través de los años de servicio a la Monarquía ${ }^{34}$.

El servicio a la Corona implica una promoción social y económica, que puede, incluso, provocar el acceso a la alta nobleza, así como el beneficio de cuantiosas mercedes económicas, siendo, en este sentido, paradigmático el caso de Andrés de Cabrera ${ }^{35}$, caso que, al no ser una excepción

de estos oficios, con todo lo que esto implicaba (Rábade ObRadó, M. P., Los judeoconversos..., págs. 748 y ss.).

${ }_{31}$ Tal como ejemplifica el caso de Fernando Álvarez de Toledo, citado en la nota anterior. Efectivamente, el secretario regio debía ejercer funciones de muy diverso tipo, a tenor de los muy distintos oficios que servía. Esto es también lo que le sucede a Andrés de Cabrera, que, a lo largo de su carrera como oficial regio, hubo de consagrarse, según las necesidades de los oficios que servia en cada momento, a tareas tan dispares como son el ejercicio de las armas, las relaciones diplomáticas, su actividad como consejero o su labor como mayordomo (RABADE Obradó, M. P., Los judeoconversos..., págs. 803 y ss.).

32 Como señala Ladero Quesada, M. A., España en 1492, págs. 110, los Reyes Católicos concedieron una gran importancia a la tarea de selección de consejos y colaboradores: "en ella, más que en grandes innovaciones institucionales, radicó el mejor funcionamiento de la maquinaria estatal y la idea posterior de unos Reyes Católicos atentos a la promoción del bien común."

${ }_{33}$ Hecho que ya resalta Chaunu, P., op . cit., vol. l, pág. 127

34 Este es el caso, por ejemplo, de Fernando del Pulgar, que sirvió, sucesivamente, a Juan II, Enrique IV y a los Reyes Católicos. El hecho de que se mantuviera leal a Enrique IV hasta el final de sus días, su negativa a incorporarse al servicio de “Alfonso XII» no evitó que, andando el tiempo, se convirtiera en uno de los más leales y señalados servidores de Isabel y Fernando (Rábade Obradó, M. P., Los judeoconversos..., págs. 603-606).

${ }_{35}$ Su acceso a la alta nobleza, en calidad de primer Marqués de Moya, se produce en el marco de las Cortes de Toledo de 1480, en agradecimiento a los muchos servicios prestados por Andrés de Cabrera y su esposa, Beatriz de Bobadilla, durante los años de contienda su- 
-en las mismas circunstancias se hallaban los Álvarez de Toledo ${ }^{36}$, o los Arias de Ávila ${ }^{37}$ - nos situaría ante un posible intento de crear una nobleza de servicio, ligada a la Corona por lazos de fidelidad inquebrantable, una nobleza dispuesta a apoyar a la Corona en las más difíciles circunstancias, si bien lo más frecuente es una promoción mucho más limitada en su gradación última ${ }^{38}$.

Paralelamente, se evidencian los fuertes lazos de fidelidad y lealtad que solían unir a estos oficiales regios con la Corona. Andrés de Cabrera, Fernando del Pulgar y Diego de Valera $^{39}$ expresaron en alguna ocasión

cesoria. El título nobiliario se vio acompañado por importantes mercedes económicas, que venían a unirse a las concedidas previamente tanto por parte de los propios Reyes Católicos como por parte de su antecesor en el trono (Molina GutiérRez, P., «Formación del patrimonio de los primeros Marqueses de Moya", En la España Medieval, 12, 1989, págs. 285-304).

${ }_{36}$ Aunque el acceso a la nobleza le fue vetado al secretario regio, no sucedió así con sus descendientes: por Real Cédula fechada en Laredo, el 6 de agosto de 1496, se concedía a su primogénito, Antonio, el título de Conde de Cedilio, con la condición de ostentarlo a partír del fallecimiento de su progenitor (el citado documento ha sido publicado, en extracto, por el CONDE DE CEDILlo, "Carta Puebla de Cedillo", Boletín de la Real Academia de la Historia, LXXIII, 1918, págs. 109-126, concretamente en la pág. 111).

${ }_{37}$ La familia accedió a la alta nobleza ya durante los últimos años del siglo xv, cuando se concedió el título de Conde de Puñoenrostro a Juan Arias de Ávila, segundogénito de Pedro Arias de Ávila (Diego, su hermano mayor, ya había fallecido), nieto, por tanto, del todopoderoso Diego de Arias de Ávila. La concesión del título se produce, además, en un momento especialmente delicado para el linaje, que acababa de atravesar una fuerte crisis, provocada por importantes problemas con el Santo Oficio (RÁBAde ObRado, M. P., Los judeoconversos..., pág. 564).

${ }_{38}$ Tal como se produce en la mayor parte de los casos, en los que el servicio de la corona supone una mejora de la posición social y económica de estos oficiales regios, pero sin grandes alardes. En esta situación se encuentra, por ejemplo, Juan de la Parra, secretario de los Reyes Católicos, para el cual el servicio a la monarquía supuso una serie de beneficios económicos, asi como el acceso a una más sólida posición social, sin más implicaciones (Rábade OBRADó, M. P., Los judeoconversos..., págs. 910-911).

${ }_{39}$ Andrés de Cabrera, en el texto del Pacto que permitió la entrada de Isabel en Segovia, refleja al menos parcialmente su visión de la situación del reino, visión que ilustra sobre los contradictorios testimonios de Cabrera, por una parte ligado a Enrique IV por inextricables lazos de lealtad, pero también sumido en el deseo de que se produjera una profunda renovación de la vida política del reino, tendente a superar la deplorable situación en la que éste se hallaba sumido en los últimos años de reinado del hermanastro de Isabel (una copia de dicho Pacto, en la Real Academia de la Historia, Colección Salazar y Castro, vol. A-7, fols. 89-91). En varias de sus Letras, Pulgar se duele de la situación del reino durante los años postreros de la estancia en el trono de Enrique IV, en críticas bastante acres, destacando de forma especial las vertidas en su Letra XXV, dirigida al Obispo de Coria, Deán de Toledo; en dicha epístola, Pulgar Ilega a afirmar que "no hay más Castillas; si no, más guerras avría...". En cuanto a Valera, recuérdense sus agrias apístolas a Juan II (publicadas por REAL DE LA RIVA, C., "Un mentor del siglo XV. Diego de Valera y sus epistolas", Revista de Literatura, XX, 1961, págs. 279-305, concretamente págs. 292 y ss.) y a Enrique IV (REAL DE LA RIVA, C., op. cit., págs. 295 y ss.), denunciando la calamitosa situación del reino y sentando los medios para superar la situación denunciada, sin dudar a la hora de fustigar los vicios y defectos de la gestión regia. Tras el acceso al trono de Isabel y Fernando, sus críticas se tornan en loas y alabanzas, que demuestran cómo el com- 
su opinión acerca de los sucesos políticos de que fueron testigos, dejando bien patente su fidelidad a la Corona, así como su deseo de un reino controlado por una Monarquía firmemente consolidada en el trono, capaz de doblegar a la levantisca nobleza, capaz de garantizar el orden interno del reino, la paz y la justicia. Testigos de los cambios introducidos por los Reyes Católicos, de las positivas consecuencias de los mismos, muestran una fe inquebrantable en los nuevos monarcas, por la promesa de un futuro mejor que parecian garantizar al reino, incluso a pesar de su condición de impulsores y protectores de la Inquisición.

Porque, efectivamente, sobre los conversos siempre se cernía, amenazadora, la sombra del Santo Oficio: ni tan siquiera los oficiales regios lograron colocarse al margen de los embates inquisitoriales. Sin embargo, habitualmente sortearon el peligro con habilidad, e incluso la desgracia de algún miembro de su familia no implicó, necesariamente, que la infamia cayera sobre todos los miembros de la misma ${ }^{40}$.

Finalmente, se hace necesario resaltar cómo estos oficiales regios de origen judio fueron capaces de triunfar en un mundo que cada vez mostraba una mayor hostilidad hacia todos aquellos que eran de su misma condición; se pone de relieve la paradoja en la que vivía la España de los Reyes Católicos: por una parte, se empezaban a colocar los cimientos de una taxativa separación entre cristianos viejos y nuevos, que colocaría a estos últimos en una muy difícil situación, relegándolos a un enojoso segundo plano, oponiéndoles barreras por doquier; por otro, esas barreras aún no se habian desarrollado lo suficiente como para impedir la posibilidad de que los conversos siguieran accediendo a puestos de respon-

portamiento de los nuevos soberanos venía a culminar las expectativas que en torno a ellos se habían desatado, ofreciendo la promesa de un futuro mejor para el reino

${ }_{40}$ Este es el caso, por ejemplo, de la familia Álvarez de Toledo, algunos de cuyos miembros se vieron sometidos a formidables embates de la inquisición, sin que los mismos tuvieran consecuencias excesivamente negativas para el linaje, que, a pesar de todo, logró salir airoso del trance, manteniendo su imparable ascenso social y económico. Uno de los hermanos del secretario regio, Fray Garcia de Zapata, Prior de La Sisla, fue condenado a la hoguera por hereje. si bien posteriormente se le rehabilitó, considerando que los judíos que le habían incriminado habian testificado en falso contra el religioso; el Canónigo y Maestrescuela toledano, Francisco Álvarez de Toledo, también fue sometido a juicio por el Santo Oficio, si bien en este caso la sentencia fue absolutoria. Un tercer miembro de la familia fue sometido a proceso inquisitorial: se trata de una mujer, cuyo nombre no ha sido posible conocer, hija de Luis Álvarez Zapata, otro hermano del secretario regio; en este caso, el proceso se suspendió, pues sólo pudieron reunirse contra la mujer una serie de acusaciones vagas y un tanto inconexas. Finalmente, el propio Fernando Álvarez de Toledo y otro pariente suyo, Juan Álvarez Zapata, fueron sospechosos de realizar determinadas prácticas judaicas, si bien, en ambos casos, ni tan siquiera se incoó procedimiento por parte del Santo Oficio (ver Rábade OBaAdo, M. P., Los judeoconversos..., págs. 632-639). 
sabilidad, al tiempo que lograban gozar de una merecida promoción económica y social.

$Y$ es indudable el destacado papel que jugaron los conversos en la construcción de la España Moderna, en sus más diversas vertientes, dando a la Historia personajes de talla y talento indiscutibles, que, pese a su origen converso, lograron hacerse con un sitio de honor en la Historia de la España Moderna ${ }^{41}$, lo que hubiera sido imposible si ese acoso social e institucional ejercido sobre los cristianos nuevos, si la Inquisición y los Estatutos de Limpieza de Sangre, así como la hostilidad de los cristianos viejos, hubieran ejercido sobre ellos una presión sin fisuras.

41 Tal como recuerda Pérez, J., op . cit., pág. 424, si bien también indica que tampoco hay que sobreestimar la intervención de los conversos en la construcción de la España Moderna, atribuyéndola un lugar excesivamente relevante, «hasta convertirlo en última instancia en la explicación de toda la historia de la España Moderna, poniendo entre paréntesis los factores económicos, sociales y políticos". 